\title{
Evaluation of Results of Ilizarov Fixator and Methodology in Tibial Non- Union
}

\author{
Jayabrata Ghosh, ${ }^{1}$ Prashanta Kumar Pujari ${ }^{1}$ \\ ${ }^{1}$ Department of Orthopaedics, Ramakrishna Mission Seva Pratisthan, Kolkata, India.
}

\begin{abstract}
Background:Treatment of non-union of tibial diaphyseal fractures has always posed a formidable challenge to surgeons. Persistant infection, deformity, bone loss, stiffness of joints and disability complicate the problem further. Ilizarov methodology tackles all the above problems simultaneously and offers a solution for non-union. Progressive new bone formation and increased vascularity following corticotomy and bone transport helps in filling bone gaps and promoting fracture union. Stability of the fixation allows early weight bearing, ambulation and joint mobilization. To evaluate the results of Ilizarov fixator in treating tibial non-union. Methods: This retrospective hospital study was conducted at Ramakrishna Mission Seva Pratishthan, Kolkata, India from August 2009 to February 2012. Forty two patients treated at this hospital between August 1994 and August 2011 with a minimum of 12 months follow up were included. The results were analysed on the outcome of bone and functional score using the Association for the Study and Application of the Method of Ilizarov (ASAMI) scoring system. Results: Of the 42 patients in this study, there were $28(66.7 \%)$ excellent, $6(14.3 \%)$ good, $5(11.9 \%)$ fair and $3(7.1 \%)$ poor bone results and $17(40.5 \%)$ excellent, $20(47.6 \%)$ good, $2(4.8 \%)$ fair and $3(7.1 \%)$ poor functional results. Conclusions: Treatment of tibial non-unions with Ilizarov fixator is effective but not without considerable amount of complications and morbidity associated with it. The functional outcome was largely multifactorial and dependent on the final joint function, soft tissue condition and ability of the patient to return to activity.
\end{abstract}

Keywords: ilizarov fixator; osteomyelitis; tibial non-union.

\section{INTRODUCTION}

The substantial incidence of tibial diaphyseal fractures continues in the face of changing pattern of injuries, from $14^{\text {th }}$ Century warfare to the modern age high velocity road traffic accidents. ${ }^{1}$ Subcutaneous position of the tibia results in high incidence of open fractures along with soft tissue damage resulting in impaired bone vascularity. The presence of infection, bone loss, excessive gap with soft tissue interposition, fracture site mobility and impaired bone vascularity increases the incidence of tibial non-union. ${ }^{1}$ In 1986, for testing bone-healing devices, a U.S. Food and Drug Administration panel defined non-union as, "established when a minimum of 9 months has elapsed since injury and the fracture shows no visible progressive signs of healing for 3 months". Multiple factors complicate long standing tibial non-union such as scarring of surrounding soft tissues from multiple surgeries, chronic osteomyelitis with multiple drug resistant microorganisms, stiffness, deformity, bone gaps, draining sinuses and disuse osteoporosis. ${ }^{2}$
Conventional treatment of infected non-unions includes extensive debridement with use of flaps or skin grafts, antibiotic bead packing, Papineau open cancellous grafting, tibiofibular synostosis and free tissue transfer including bone transplants. Secondary procedures are often required for correction of bone defects and deformity. Results are multiple surgeries with joint stiffness and oedema, interfering with optimal limb function. ${ }^{3}$

Prof. Ilizarov employed biological techniques and a system of external fixation as a multimodal approach to the management of non-union. Any size of defect can be regenerated by progressive histiogenesis at the corticotomy site by Ilizarov technique. Because the level at which the regenerate bone is formed is healthy, infection can be eradicated at one site while the bone is regenerated at another site, which not only saves time but also significantly increases local vascularity. ${ }^{4}$ The use of a highly modular apparatus allows an assembly of an unlimited number of configurations. The frame can be used

Correspondence: Dr. Jayabrata Ghosh, Department of Orthopaedics, Ramakrishna Mission Seva Pratisthan, Kolkata, India. Email: drjayabrata.ghosh@gmail.com. Phone: +91-9748270986. DOI:10.3126/jcmsn.v15i2.19479. Article received:. 2018-03-18. Article accepted: 2019-5-28. 
to overcome deformities while at the same time permitting weight bearing ambulation and joint mobilization. ${ }^{5}$ The objective of this study is to evaluate the results of Ilizarov fixator and methodology in treating tibial non-union by assessment of bone healing and functional results according to a modified Association for the Study and Application of the Method of Ilizarov Foundation (ASAMI) criteria. ${ }^{3,4}$

\section{METHODS}

This was a retrospective hospital based study conducted at Ramakrishna Mission Seva Pratishthan, Kolkata, India from August 2009 to February 2012. Forty two patients treated at this hospital between August 1994 and August 2011 with a minimum of 12 months follow up with Ilizarov fixator for tibial diaphyseal non-union were included. While the inclusion criteria involved established tibial non-union with a bone gap of $2 \mathrm{~cm}$ or more, the exclusion criteria included patients with less than 12 months follow up or with inadequate clinical records or who opted for fixator removal prior to completion or who underwent limb amputation. Additionally, the operative technique and follow-up included several steps as elaborated next. All unhealthy fibrous tissues and bone were excised. The resultant gap was measured and decision made regarding acute docking and or bone grafting. The assembly was opened like clam shell and brought around the limb. The main proximal frame supporting ring was stationary. The stabilizing frame supporting ring was applied most distally. The pusher- puller ring was applied distal to fracture-osteotomynonunion site. The reference ring was used as a reference for supporting rings or distraction compression rings. Wires were tensioned by tensioner at $130 \mathrm{kgs}$ for wires fixed to full rings and $90 \mathrm{kgs}$ for half rings. Stopper wires were used for cancellous bone, osteoporotic bones, and deformity correction and inter-fragmentary compression. Corticotomy was performed at metaphyseo-diaphyseal junction in cases intended for bifocal compression along with fibular osteotomy. Distraction / compression started after 5 - 7 days of operation. Rate was kept at 0.25 to 0.5 $\mathrm{mm}$ each time, 4 times per day. If laxity was more than 7 degrees, then hypertrophic nonunion was first compressed for 2-3 weeks followed by gradual distraction. If end to end bone contact was satisfactory following docking then bone ends were compressed for 2- 3 weeks followed by distraction. Post operatively, knee and ankle exercises were initiated and walking with support started as soon as tolerated. X-rays of the limb were obtained after 7 to 10 days to confirm distraction. Patients were discharged on 14 to 21 days of operation and were called back every 3 weeks during compression distraction phase and every 4 weeks during consolidation phase. Patients were followed up in the outpatients department. Pin tracts were checked for infection. Transfixion wires were checked for loosening and re-tensioned accordingly. Frame was removed after radiological union in 3 of 4 cortices and no fracture site movement. The limb was put in a patella tendon bearing cast and allowed full weight bearing and final x-rays obtained after 6 to 8 weeks before removal of cast. Patients were further followed up for a minimum period of 12 months addressing joint stiffness, pain and complaints regarding any discharge or soft tissue ailments.

\section{RESULTS}

Forty two cases were evaluated in this study and the results are indicated. The patient characteristics are described in (Table 1). Six cases of bifocal treatment had delayed

\begin{tabular}{|c|c|}
\hline \multicolumn{2}{|c|}{$\begin{array}{l}\text { Table 1. Characteristics of the } 42 \text { patients } \\
\text { involved in this study }\end{array}$} \\
\hline Parameters & Value(N=42) \\
\hline Age, $y($ mean $\pm S D$, range $)$ & $35.8 \pm 14.4(7-66)$ \\
\hline Gender (M:F) & $34: 8(81 \%, 19 \%)$ \\
\hline Site of initial fracture & $\begin{array}{l}\text { Diaphyseal lower1/3-7 } \\
(16.7 \%) \\
\text { Diaphyseal Middle third- } \\
26(61.9 \%) \\
\text { Diaphyseal upper third- } 9 \\
(21.4 \%)\end{array}$ \\
\hline Comorbidities & Diabetic-3, smoker-17 \\
\hline Type of initial injury & $\begin{array}{l}\text { Closed fracture }-13(31 \%) \\
\text { Open fracture-29(69\%) }\end{array}$ \\
\hline Mechanism of injury & $\begin{array}{l}\text { RTA }(59.5 \%) \text {, fall from a } \\
\text { height }(23.8 \%) \text {, crush } \\
(7.1 \%) \text {, gunshot }(2.4 \%) \text {, } \\
\text { industrial accident }(4.8 \%) \text {, } \\
\text { natural disaster }(2.4 \%)\end{array}$ \\
\hline Prior surgery & $\begin{array}{l}\text { Plating } 5(11.96 \%) \text {, exter- } \\
\text { nal fixator } 28(66.67 \%) \\
\text { plaster cast immobilization } \\
2(4.76 \%) \text { or nailing } 7 \\
(16.67 \%)\end{array}$ \\
\hline Type of Non- union & $\begin{array}{l}\text { Atrophic- } 69 \% \text {, hypertro- } \\
\text { phic- } 31 \%\end{array}$ \\
\hline Pre-operative infection & $\begin{array}{l}\text { Absent- } 18(42.9 \%) \text {, Pre- } \\
\text { sent- } 24(57.1 \%)\end{array}$ \\
\hline $\begin{array}{l}\text { Paley's type of Non- } \\
\text { union }\end{array}$ & $\begin{array}{l}\text { B1- } 10(23 \%), B 2-24 \\
(57 \%), \text { B3- 8(19\%) }\end{array}$ \\
\hline $\begin{array}{l}\text { Average Injury to } \\
\text { Ilizarov fixator interval }\end{array}$ & 45.9 weeks (36-84 weeks) \\
\hline $\begin{array}{l}\text { Average bone gap(mean, } \\
\text { range) }\end{array}$ & $4.1 \mathrm{~cm}(2-15 \mathrm{~cm})$ \\
\hline
\end{tabular}


Ghosh et al. Evaluation of Results of Ilizarov Fixator and Methodology in Tibial..

\begin{tabular}{|c|c|}
\hline $\begin{array}{l}\text { Procedure/ } \\
\text { Outcome }\end{array}$ & No. of cases $(\mathrm{N}=42)$ \\
\hline $\begin{array}{l}\text { Type of compres- } \\
\text { sion/distraction }\end{array}$ & $\begin{array}{l}\text { Monofocal- 23(54\%), bifocal- } 19 \\
(45.2 \%)^{*}\end{array}$ \\
\hline Bone grafting & $13(31 \%)-12$ iliac, 1 fibular \\
\hline Acute docking & $30(71.4 \%)$ \\
\hline Corticotomy & $\begin{array}{l}\text { Distal- } 7(16 \%) \\
\text { Proximal-26(62\%) } \\
\text { None-9 }(21.4 \%)\end{array}$ \\
\hline Union & $41(97.6 \%)$ \\
\hline Return to activity & $\begin{array}{l}\text { Previous activity-16(38\%) } \\
\text { Alternative activity- 23(55\%) } \\
\text { Unemployed-3(7\%) }\end{array}$ \\
\hline $\begin{array}{l}\text { Average duration } \\
\text { of compression }\end{array}$ & 38.1 weeks \\
\hline $\begin{array}{l}\text { Average duration } \\
\text { of distraction }(n=19)\end{array}$ & 78.3 weeks \\
\hline Residual infection & $4(9.5 \%)$ \\
\hline $\begin{array}{l}\text { Average frame } \\
\text { duration }\end{array}$ & 7.3 months(3.5-21 months) \\
\hline $\begin{array}{l}\text { Average plaster } \\
\text { cast duration }\end{array}$ & 1.9 months( $1.5-3$ months $)$ \\
\hline Average follow up & 57.14 months \\
\hline Complications & $\begin{array}{l}\text { Pin tract infection- } 40(95 \%) \text {, refrac- } \\
\text { ture- } 1(12 \%) \text {, nerve palsy-3(7.1\%), } \\
\text { reflex sympathetic dystrophy-9.5\%, } \\
\text { ankle stiffness- } 7(17 \%) \text {, knee stiff- } \\
\text { ness- } 5(11.9 \%) \text {, subtalar joint stiff- } \\
\text { ness-26(62\%) }\end{array}$ \\
\hline $\begin{array}{l}\text { Average Patient } \\
\text { satisfaction on } 0 \text { - } \\
100 \text { VAS }\end{array}$ & $76 \pm 24.8$ \\
\hline \multicolumn{2}{|c|}{$\begin{array}{l}\text { *monofocal- compression followed by distraction at docking, } \\
\text { bifocal- distraction at corticotomy and compression at non- } \\
\text { union site. }\end{array}$} \\
\hline
\end{tabular}

\begin{tabular}{|c|c|c|}
\hline \multicolumn{3}{|c|}{$\begin{array}{l}\text { Table 4. Results using Association for the } \\
\text { Study and Application of the Methods of } \\
\text { Ilizarov (ASAMI) scoring system. }\end{array}$} \\
\hline \multicolumn{3}{|c|}{ A. Bone Results } \\
\hline Condition & Description & No. \\
\hline Excellent & $\begin{array}{l}\text { Union, No infection, Deformity }<7^{\circ} \text {, } \\
\text { Limb Length Discrepancy }<2.5 \mathrm{~cm}\end{array}$ & 28 \\
\hline Good & $\begin{array}{l}\text { Union }+ \text { any two of the following; Ab- } \\
\text { sence of infection, }<7 \text { deg deformity } \\
\text { and limb length discrepancy of }<2.5 \\
\mathrm{~cm}\end{array}$ & 6 \\
\hline Fair & $\begin{array}{l}\text { Union plus one of the following; Ab- } \\
\text { sence of infection, }<7 \text { deg deformity } \\
\text { and limb length discrepancy of }<2.5 \mathrm{~cm}\end{array}$ & 5 \\
\hline Poor & $\begin{array}{l}\text { Nonunion/ refracture/ union plus infec- } \\
\text { tion plus deformity }>7 \mathrm{deg} \text { and limb } \\
\text { length discrepancy }>2.5 \mathrm{~cm}\end{array}$ & 3 \\
\hline Total & & 42 \\
\hline
\end{tabular}

\begin{tabular}{|c|c|c|}
\hline \multicolumn{3}{|c|}{ 5. Functional Results. } \\
\hline Condition & Description & No. \\
\hline Excellent & $\begin{array}{l}\text { Active*, no limp, minimum stiffness } \\
{[\text { Loss }<15 \text { deg knee extension/< } 15} \\
\text { degrees dorsiflexion of ankle], No reflex } \\
\text { sympathetic dystrophy [RSD], insignifi- } \\
\text { cant pain }\end{array}$ & 17 \\
\hline Good & $\begin{array}{l}\text { Active* with one or two of the follow- } \\
\text { ing: limp, stiffness, RSD, significant } \\
\text { pain }\end{array}$ & 20 \\
\hline Fair & $\begin{array}{l}\text { Active* with three or all of the follow- } \\
\text { ing; limp, stiffness, RSD, significant } \\
\text { pain }\end{array}$ & 2 \\
\hline Poor & $\begin{array}{l}\text { Inactive [Unemployment or inability to } \\
\text { return to daily activities due to injury] }\end{array}$ & 3 \\
\hline \multicolumn{2}{|l|}{ Total } & 42 \\
\hline \multicolumn{3}{|c|}{$\begin{array}{l}\text { *Active }=\text { Patient returning to his previous activity level or } \\
\text { finding an alternative activity to sustain a livelihood, was } \\
\text { considered active. }\end{array}$} \\
\hline
\end{tabular}

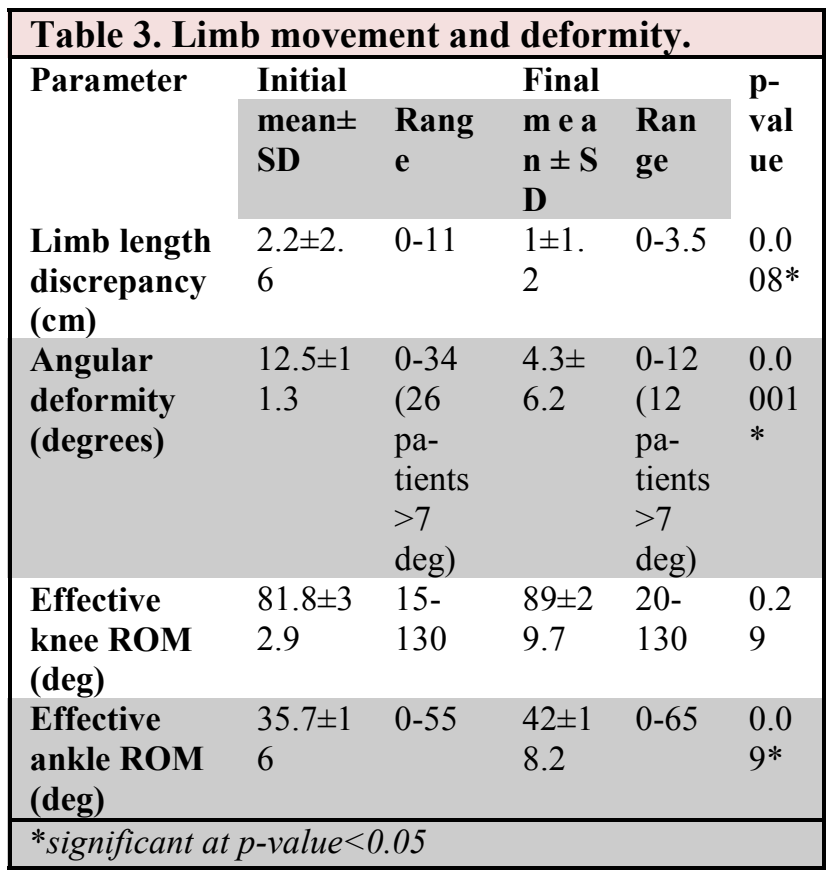

consolidation at distraction site. Four cases had delayed non-union site consolidation out of which 1 failed to unite after 18 months. Repeat corticotomy $\left\{\left(x_{1}\right.\right.$

Figure 1. Infected non-union of tibia in a $7 \mathrm{yr}$ old male patient: a) Pre-operative radiographs of nonunion tibia with intramedullary implants insitu, b) Postoperative radiographs on day 64 showing evidence of early union, and c) Radiographs at 12 months showing a complete union of tibia. 
Ghosh et al. Evaluation of Results of Ilizarov Fixator and Methodology in Tibial..

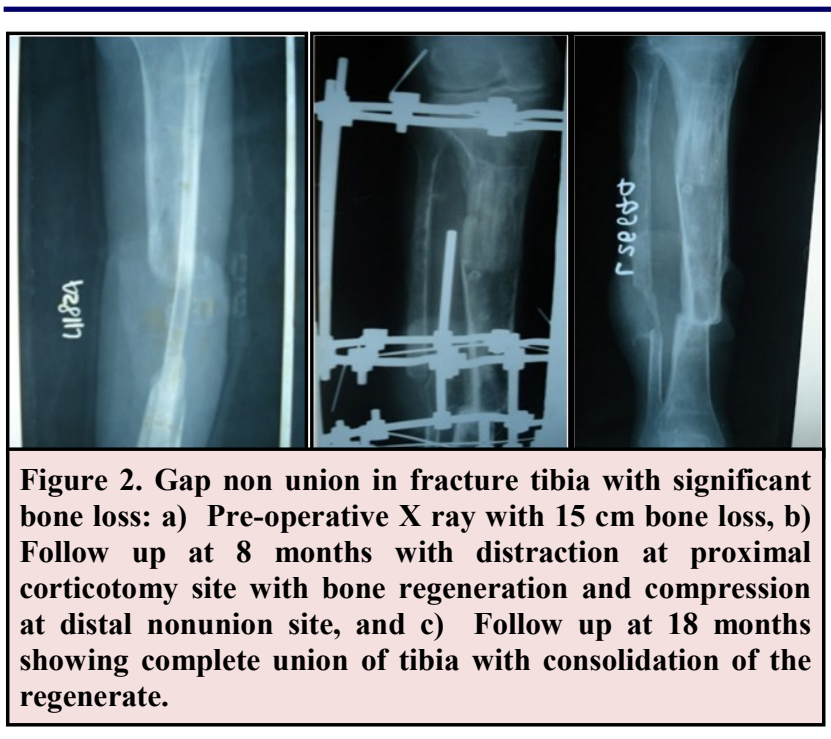

\section{DISCUSSION}

Ilizarov fixator and its methodology allow the treating surgeon an opportunity to overcome the factors to reach the desired goal. Recycling of rings and undamaged components between patients, as in other studies ${ }^{6}$ helped in bringing down the financial burden. Adequate glycaemic control in 3 diabetic patients was undertaken prior to treatment procedures. High incidences of smokers was noted in the study population and were actively discouraged during treatment. Smoking has has been shown to lengthen treatment time. ${ }^{7}$ Twenty four patients had infection at the non-union site as compared to $50 \%$ of patients in series by Paley et $\mathrm{al}^{4}$. This indicates that infection is not only the cause but also a principal element to consider eradication for union to take place. There was an improvement in the limb length discrepancy and deformity in the final outcome. The final effective range of movement of knee and ankle showed overall improvement. Subtalar joint stiffness if present before treatment persisted so after treatment. The mean time interval from injury to Ilizarov was 11.5 months compared to 7.8 months in series by Madhusudhan et al. ${ }^{3}$ and 3.5 years in series by Paley et al. ${ }^{4}$ All type B1 underwent bifocal treatment, 23 of type B2 had monofocal and 1 underwent bifocal treatment and all of B3 underwent bifocal treatment. In Paley's series 6 patients with B1 had bifocal treatment, 10 patients with type B2 had bifocal treatment and 3 had monofocal treatment and 3 of B3 had bifocal treatment with internal and external lengthening, 1 had trifocal treatment and 2 had bifocal treatment with internal lengthening ${ }^{4}$. Acute docking of non-union site was done wherever possible except in large gaps. Gene D. Bobroff has advocated bone grafting as an additional procedure in the docking area in case of delayed consolidation to shorten fixator duration. ${ }^{8}$ The total treatment period lasted over a mean period of 9.0 months. Paley et al in their study had a mean total treatment period of 10.6 months in patients undergone bifocal treatment. ${ }^{4}$ In our study, we considered an active individual to be inclusive of patients who returned to previous activity as well as finding an alternative activity to sustain a livelihood. In our country with no social benefits, patients had to return to their job at the earliest or search for a less demanding one. Limp in patients with shortening of $2 \mathrm{~cm}$ or more was well compensated by shoe raise. The mean overall satisfaction was $76 \%$. The result was comparable with the study by Sanders et al who demonstrated $77 \%$ overall satisfaction in their series. ${ }^{12}$

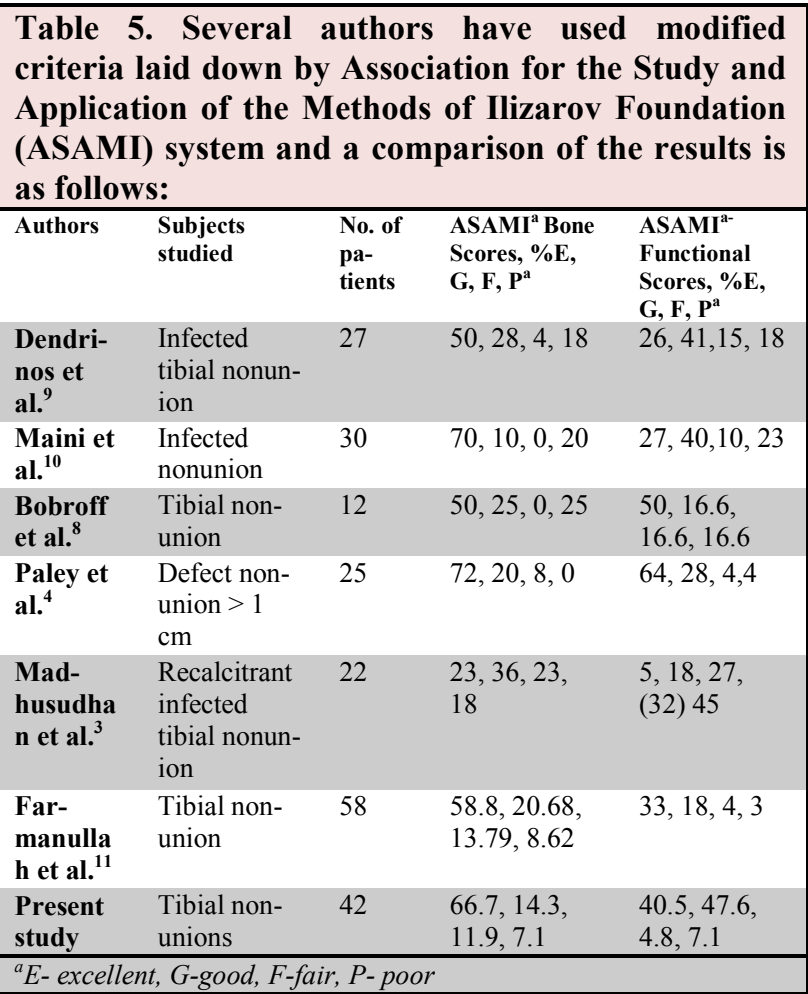

\section{CONCLUSIONS}

The author would like to thank all the patients for giving consent to participate in the study.Observations in this study suggest that Ilizarov ring fixator and methodology is an efficient device in treating established cases of tibial non-unions. The ability to achieve an excellent bony result does not mandate an excellent functional result. The resultant functional result is dependent on multiple factors including range of movement, neurovascular status and ability for the patient to return to activity. Patients who were already heavily burdened due to their socioeconomic status along with lost resources in previous surgeries and admissions found the results 
to be satisfying but "union" came at a heavy price. Hence patient selection and counseling is of paramount importance. Issues regarding the lengthy time of treatment, additional procedures and considerable amount of complications must be fully explained by the surgeon and understood by the patient prior to commencement of treatment. There are considerable amount of complications and morbidity associated with the treatment

\section{REFERENCES}

1. Green DP, Bucholz RW, Heckman JD, CourtBrown CM. Fractures of Tibia and Fibula. Rockwood and Green's Fractures in Adults: 6th Ed. 2006; 2: Pg. 2079-2143.

2. Gustilo RB. Management of infected fractures. Surgery of Musculoskeletal System: C McCollister Evarts. II. 1990. Pg. 4429.

3. Madhusudhan TR, Ramesh B, Manjunath KS, Shah HM, Sundaresh DC, Krishnappa N. Outcomes of Ilizarov ring fixation in recalcitrant infected tibial non-unions - a prospective study. Journal of Trauma Management \& Outcomes. 2008 Jul 23;2(1)

4. Paley D, Catagni MA, Argnani F, Villa A, Benedetti GB, Cattaneo $R$, et al. Ilizarov treatment of tibial nonunions with bone loss. Clinical orthopaedics and related research. 1989;(241):146.

5. Shahid M, Hussain A, Bridgeman P, Bose D. Clinical outcomes of the Ilizarov method after an infected tibial nonunion. Arch trauma Res 2013;2(2):71-5.

6. Chaudhary MM. Infected nonunion of tibia. Indian J Orthop 2017;51(3):256-68.

7. Chaudhuri A, Datta S, Chowdhury A, Singh A, procedure. A strategized postoperative rehabilitation program is followed in which the patient is an active participant. The key to success lies in the proficiency of the surgeon, a thorough knowledge of the anatomy, familiarization of components of the system and their multimodal utility, understanding the biology of nonunion, watchful documentation and individualized care of the patient.
Ghosh S, Roy D. Ilizarov fixator in management of nonunited and infected tibial shaft fractures. Med J Dr DY Patil Univ 2015;8 (1):35.

8. Bobroff GD, Gold S, Zinar D, others. Ten year experience with use of Ilizarov bone transport for tibial defects. Bulletin (Hospital for Joint Diseases (New York, NY)). 2003;61(3-4):101.

9. Dendrinos GK, Kontos S, Lyritsis E, others. Use of the Ilizarov technique for treatment of non-union of the tibia associated with infection. The Journal of bone and joint surgery. American volume. 1995;77(6):835

10. Maini L, Chadha M, Vishwanath J, Kapoor S, Mehtani A, Dhaon BK. The Ilizarov method in infected nonunion of fractures. Injury. 2000;31 (7):509-17.

11. Farmanullah, Khan MS, Awais SM. Evaluation of management of tibial non-union defect with Ilizarov fixator. J Ayub Med Coll Abbottabad. 2007 Sep;19(3):34-6.

12. Sanders DW, Galpin RD, Hosseini M, MacLeod $\mathrm{MD}$, others. Morbidity resulting from the treatment of tibial nonunion with the Ilizarov frame. Can J Surg. 2002;45(3):196-200.

Citation: Ghosh J, Pujari PK. Evaluation of Results of Ilizarov Fixator and Methodology in Tibial NonUnion. JCMS Nepal. 2019; 15(2):98-102. 